\title{
Overcoming Antisemitic Biases in Christian Religious Education
}

\section{Introduction}

This article presents the results of my dissertation, wherein I researched the question of how to overcome antisemitic biases in Christian Religious Education. The existence of antisemitic biases in everyday life of youth has been shown by the sociologist Barbara Schäuble. In her research on constructions of difference and common antisemitism, she interviewed teenagers and discovered that they reproduce anti-Jewish stereotypes, naively assuming these notions to be grounded in facts. When asked about the source of this "knowledge," they name history class, ethics class, and classes in religious education. ${ }^{1}$

One would like to assume that today's world of Christian education is free of antisemitic biases, because since the Shoah much has been done in Christian theology to combat this phenomenon. So the question remains how religious instruction that is informed by this theology could engender negative biases toward the Jewish people. If my assumption is correct, Schäuble's discovery actually points to an even larger issue: Subtle forms of antisemitism appear time and time again on the part of Christians who have experienced religious education. Here's an example of a student of theology who wrote an open letter to the makers of the movie The Passion of Christ by Mel Gibson saying that she considers it incredibly morbid to hear the chief rabbi of Vienna say that crucifixion was not a Jewish execution method and that the Romans were the ones who killed Jesus. She accuses Jews of secretly commissioning the murder, because Pilate never would have come up with the idea if it hadn't been for their completely irrational accusations, since religious matters were of no interest to the Romans, she states. ${ }^{2}$

It is quite possible that the student is not aware of how problematic her statement really is, because she assumes her accusation of murder rests solidly upon the historical facts she learned about in class. In any case, she would cer-

1 B. Schäuble, "Anders als wir": Differenzkonstruktionen und Alltagsantisemitismus unter Jugendlichen Anregungen für die politische Bildung (Berlin: Metropol, 2012), 392.

2 H. P. Wassermann, "Zwischen Stagnation und Modernisierung: Antisemitismus in Österreich," in Feindbild Judentum: Antisemitismus in Europa, ed. L. Rensmann and J. H. Schoeps (Berlin: VBB Verlag für Berlin-Brandenburg, 2008), 217-18.

Ә OpenAccess. (C) 2022 Julia Spichal, published by De Gruyter. (cc))BY-NC-ND This work is licensed under the Creative Commons Attribution-NonCommercial-NoDerivatives 4.0 International License. 
tainly deny claims of antisemitism on her part because open animosity toward the Jewish people has been considered taboo in Austria and Germany since the Shoah. Yet prejudices toward Jews are still prevalent and continue to appear in public discussions disguised as "hard facts," as this example shows. Werner Bergmann and Rainer Erb have dubbed this phenomenon the "functional latency" of antisemitism. ${ }^{3}$

The theology student may be claiming historicity or be referring to something she heard in religion class. We don't know exactly. In any case: The fact alone that such antisemitic prejudices are being circulated as so-called facts is a serious problem and is testament to the tenacity of antisemitism. Apparently Christian religious education is a contributing factor.

\section{Empirical Findings}

Examining religious instruction directly is a tricky matter, so I decided to analyze curricula and school books in order to find the root of the problem. Curricula determine what goes into school books and are intended as standards for religious education. They are therefore an ideal starting point for an analysis of biases purported in religious education. Nevertheless, it is not possible to judge the quality of instruction in class based solely on these findings.

A research project headed by Günter Biemer pioneered this field of study in 1977. ${ }^{4}$ Later research projects were completed by 1995 after which there was a long twenty-year gap that preceded my dissertation. The scientists on Biemer's team developed a system of categories for qualitative content analysis to identify antisemitic prejudices in curricula and school books. ${ }^{5}$ Three studies by Peter Fiedler, ${ }^{6}$ Helga Kohler-Spiegel, ${ }^{7}$ and Martin Rothgangel ${ }^{8}$ used this system. They concluded that the curricula and school books for Catholic and Protestant religious education analyzed in Germany and Austria use antithetical patterns of

3 W. Bergmann and R. Erb, "Kommunikationslatenz, Moral und öffentliche Meinung: Theoretische Überlegungen zum Antisemitismus in der Bundesrepublik Deutschland,” Kölner Zeitschrift für Soziologie und Sozialpsychologie 38, no. 2 (1986): 226.

4 P. Fiedler, Das Judentum im katholischen Religionsunterricht: Analysen, Bewertungen, Perspektiven (Düsseldorf: Patmos, 1980), 11.

5 Ibid.

6 Ibid.

7 H. Kohler-Spiegel, Juden und Christen-Geschwister im Glauben: Ein Beitrag zur Lehrplantheorie am Beispiel Verhältnis Christentum Judentum (Freiburg im Breisgau: Herder, 1991).

8 M. Rothgangel, Antisemitismus als religionspädagogische Herausforderung: Eine Studie unter besonderer Berücksichtigung von Röm 9-11 (Freiburg im Breisgau: Herder, 1997). 
valuation to highlight Christianity in contrast to Judaism. The following topics turned out to be particularly sensitive in this context:

- The responsibility for Jesus' death

- Jesus' relationship with the Pharisees

- the Hebrew Bible as the sacred text of modern-day Judaism

- the Jewish understanding of the Torah

- Jewish history between 70 C.E. and the Shoah and

- $\quad$ the State of Israel

Another finding was that none of the curricula and school books examined offered a positive vision of Jewish-Christian relations.

What has changed since 1995? This question was the common thread throughout my dissertation. More specifically I asked myself the following questions: How is the relationship between Judaism and Christianity portrayed in current curricula and school books in Germany and Austria in the context of these sensitive topics? And: In what way, if any, has the portrayal of Judaism changed compared to the previous analyses?

In order to ensure comparability between my study and those of my predecessors I applied the same methodology used in the previous studies to my dissertation in order to compare the findings. Furthermore, I examined new versions of the curricula and school books analyzed by my predecessors. In addition, I chose to take a look at some of the most popular school books in use for my study that haven't so far been analyzed.

In this article I will limit myself to a presentation of my results in the context of Jesus' relationship with the Pharisees. ${ }^{9}$ The Pharisees are the most frequently mentioned Jewish group in curricula and school books. Their supposed rigor and faith in justification by works are presented as opposing Jesus' teaching. The school books I examined tend to present issues that are really conflicts between Jesus and the Pharisees as being between Christianity and Judaism in general. Furthermore this issue is intertwined with the responsibility for Jesus' death and the Jewish understanding of the Torah. That's why the relationship between Jesus and the Pharisees is the most important of these sensitive topics in my opinion.

The studies I mentioned earlier all came to the same conclusion: While the school books examined admit to the fact that Jesus was himself a Jew, they tend

9 For more findings, see J. Spichal, Vorurteile gegen Juden im christlichen Religionsunterricht: Eine qualitative Inhaltsanalyse ausgewählter Lehrpläne und Schulbücher in Deutschland und Österreich (Göttingen: V\&R Unipress, 2015). 
to follow this admission with passages from the Bible that stress his opposition to Jewish practices. The framing and rhetorical set-up of these chapters makes it appear as though Jesus was opposed to Judaism as a whole. This problem still exists. Let me illustrate this by examining a school book currently in use:

The following passages are taken from the appendix of the school book RELi + wir ${ }^{10}$ which is in use in Germany and Austria. The first passage emphasizes the fact that Jesus was a Jew and that he plays an integral part in the story of the people of Israel:

Jesus war Jude. Er gehört zu dem Volk, das sich als Nachkommenschaft der Kinder des Erzvaters Israel (Jakob) betrachtet. Er steht damit in der langen Geschichte einer Familie, eines Volkes und in der Geschichte dieser Familie und dieses Volkes mit Gott. ${ }^{11}$

Only twenty pages later, it says that Jesus broke the Sabbath rules of THE Jews in order to heal the sick:

Jesus hat die Sabbatvorschriften der Juden manchmal bewusst gebrochen, z. B. um zu heilen. Er wollte zeigen: Der Sabbat ist für den Menschen da. Aber der Sabbat soll niemanden hindern, Gutes zu tun oder sich und anderen eine Freude zu bereiten. ${ }^{12}$

Jesus is presented as having been the one to correctly interpret the rules of the Sabbath. Thereby it is implied that Judaism and Christianity split during Jesus' lifetime.

The three studies also showed that school books construct a causal relation between Jesus' conflicts with the Pharisees and his execution. This hasn't changed either as this example illustrates: The authors of the German school book Kursbuch Religion elementar for grades seven and eight went so far as to compose an imaginary conversation between the Pharisees and the Zealots, in which both these groups express their indignation over Jesus' teaching about the Sabbath and the fact that many have started seeing him as the son of God. Finally a Pharisee by the name of Aaron says that Jesus must be dealt with violently, because more and more people are beginning to follow him, and this will harm his group of Pharisees:

10 RELi is an abbreviation for "religion." In German it is common among students to call classes in religious education "Reli."

11 I. Kirchhoff and S. Dievenkorn, eds., RELi + wir (Österreich-Ausgabe, Göttingen, Wien: Vandenhoeck \& Ruprecht; Evangelischer Presseverband, 2010), 269.

12 Ibid., 289. 
Aaron: Die Römer stören mich eigentlich nicht so sehr. Wenn die da sind, herrscht wenigstens Ruhe und Ordnung. Aber dass Jesus sich als Jude nicht an unsere religiösen Vorschriften hält, ist eine Unverschämtheit. Ihr wisst doch noch, wie er das Sabbatgebot gebrochen hat. [...]

Benjamin: Aber viele laufen ihm nach.

Aaron: Das ist ja das Schlimme. So einer findet immer mehr Anhänger, und uns glaubt bald keener mehr was. Am besten wäre, wenn er verschwinden würde. ${ }^{13}$

The school book for grades five and six from the series Religion entdecken, verstehen, gestalten presents us with a passage about the Pharisees during the time of Jesus, mentioning the fact that conflicts between them and Jesus were common and contributed to the development of the Jewish theology. It also says that Jesus himself may well have been a Pharisee according to some researchers. This is one of the rare examples of a nuanced discussion of Jesus' relationship with the Pharisees:

Pharisäer sind oft Lehrer in Synagogen, denn die religiöse Bildung des Volkes liegt ihnen sehr am Herzen. Auch Jesus hat ihnen nahe gestanden. Manche Wissenschaftler meinen sogar, dass er selbst ein Pharisäer gewesen sei. Heftige Streitgespräche und Diskussionen waren unter Pharisäern üblich, sie waren eine gute Schulung bei der Suche nach Lösungen. ${ }^{14}$

During my analysis I was confronted with a serious problem: The system of categories couldn't be applied to a particular book, because it is meant for primary education as this example shows: The authors of the series Wegzeichen Religion seem to have been aware of the risk involved in putting blame on the Pharisees. In their first volume while treating the topic of Jesus' affection toward sinners, they refer to Jesus' adversaries simply as "people” to avoid negative clichés:

Die Leute sagen: "Mit Zöllnern setzt man sich nicht an einen Tisch. Sie nehmen mehr Geld, als recht ist." 15

13 W. Eilerts and H.-G. Kübler, eds., Kursbuch Religion Elementar: Ein Arbeitsbuch für den Religionsunterricht im 7. / 8. Schuljahr (Stuttgart, Braunschweig: Calwer Verlag; Diesterweg, 2004), 137.

14 S. Baden-Schirmer, G.-R. Koretzki, and R. Tammeus, eds., Religion entdecken, verstehen, gestalten: Ein Unterrichtswerk für den evangelischen Religionsunterricht (Göttingen: Vandenhoeck \& Ruprecht, 2008), 79.

15 G. Miederer, Wegzeichen Religion 1: Ein Unterrichtswerk für den evangelischen Religionsunterricht in der Jahrgangsstufe 1 (Frankfurt a. M.: Diesterweg, 2001), 24. 
According to the system of categories we must nonetheless rate this passage as tendentious. ${ }^{16}$ A reformulation of the system of categories was necessary, since this assessment conflicts with the intentions of its creators. This was one of the methodical steps I carried out in my dissertation from a subject didactics perspective. Therefore I drew on new findings in the fields of Jewish and biblical studies and integrated these findings with the experiences and approaches of pupils.

\section{Recommendations}

The following passage presents my recommendations to overcome antisemitic biases in Christian religious education at primary schools:

Whenever we make any attempt to portray Jesus' relationship to the Pharisees, it is imperative to establish unequivocally that Jesus was a Jew and that therefore it doesn't make any sense to insinuate antagonism between him and "the Jews." This is especially important when treating Jesus' teaching about the Sabbath and his care of sinners. It is also vital to keep in mind that we cannot address polemics aimed at Pharisees from the New Testament until students reach the age of at least ten, because this task requires the ability to reflect on a meta level.

In primary education this topic should therefore be treated in the following way:

1. The Pharisees and Jesus often disagreed, yet according to the Gospel of Luke Jesus was a regular guest in the houses of Pharisees, which implies that they were basically on good terms.

2. The Pharisees and Jesus were in agreement about two of the most crucial elements of the Hebrew faith: The main teachings of the Torah and the hope of resurrection.

In order to avoid insinuating a causal connection between this conflict and Jesus' crucifixion, authors of school books should avoid relating these events in sequence. Pontius Pilate should instead be portrayed as being responsible for Jesus' crucifixion. These recommendations foster a nuanced portrayal of Jesus' relationship with the Pharisees in the context of primary school education.

16 Fiedler, Das Judentum im katholischen Religionsunterricht, 65-66. 
Julia Spichal wrote her dissertation on "Prejudices against Jews in Christian Religious Education" as a pre-doc assistant at the Institute for Religious Education at the Faculty of Protestant Theology in Vienna. She now works as a teacher of Protestant Religious Education and Latin.

\section{References}

\section{Primary Sources}

Baden-Schirmer, Sigrid, Gerd-Rüdiger Koretzki, and Rudolf Tammeus, eds. Religion entdecken, verstehen, gestalten: Ein Unterrichtswerk für den evangelischen Religionsunterricht. Göttingen: Vandenhoeck \& Ruprecht, 2008.

Eilerts, Wolfram, and Heinz-Günter Kübler, eds. Kursbuch Religion Elementar: Ein Arbeitsbuch für den Religionsunterricht im 7. / 8. Schuljahr. Stuttgart, Braunschweig: Calwer Verlag; Diesterweg, 2004.

Kirchhoff, Ilka, and Sabine Dievenkorn, eds. RELi + wir. Österreich-Ausgabe Göttingen, Wien: Vandenhoeck \& Ruprecht; Evangelischer Presseverband, 2010.

Miederer, Gertrud. Wegzeichen Religion 1: Ein Unterrichtswerk für den evangelischen Religionsunterricht in der Jahrgangsstufe 1. Frankfurt a. M.: Diesterweg, 2001.

\section{Secondary Sources}

Bergmann, Werner, and Rainer Erb. "Kommunikationslatenz, Moral und öffentliche Meinung: Theoretische Überlegungen zum Antisemitismus in der Bundesrepublik Deutschland." Kölner Zeitschrift für Soziologie und Sozialpsychologie 38, no. 2 (1986): 223-46.

Fiedler, Peter. Das Judentum im katholischen Religionsunterricht: Analysen, Bewertungen, Perspektiven. Düsseldorf: Patmos, 1980.

Kohler-Spiegel, Helga. Juden und Christen-Geschwister im Glauben: Ein Beitrag zur Lehrplantheorie am Beispiel Verhältnis Christentum Judentum. Freiburg im Breisgau: Herder, 1991.

Rothgangel, Martin. Antisemitismus als religionspädagogische Herausforderung: Eine Studie unter besonderer Berücksichtigung von Röm 9-11. Freiburg im Breisgau: Herder, 1997.

Schäuble, Barbara. "Anders als wir": Differenzkonstruktionen und Alltagsantisemitismus unter Jugendlichen Anregungen für die politische Bildung. Berlin: Metropol, 2012.

Spichal, Julia. Vorurteile gegen Juden im christlichen Religionsunterricht: Eine qualitative Inhaltsanalyse ausgewählter Lehrpläne und Schulbücher in Deutschland und Österreich. Göttingen: V\&R Unipress, 2015.

Wassermann, Heinz P. "Zwischen Stagnation und Modernisierung: Antisemitismus in Österreich." In Feindbild Judentum: Antisemitismus in Europa, edited by Julius H. Schoeps and Lars Rensmann, 217-60. Berlin: VBB Verlag für Berlin-Brandenburg, 2008. 
